\title{
EFFECT OF GINGER EXTRACT ON GASOLINE ASSOCIATED IMMUNITOXICITIES IN WISTAR RATS
}

\author{
G.O.OBOCHI, S.P.MALU, A.E.ABARA, O.R.OGRI AND N.O.ALOBI
}

(Received 10, July 2008; Revision Accepted 6, November 2008)

\begin{abstract}
Effect of ginger extracts on gasoline associated immunotoxicities in wistar rats was studied. Fifteen wistar rats were randomly assigned into three study groups. Group 1 was the control, while groups 2 and 3 received daily treatment by inhalation of gasoline vapour. The animals in group3 were also treated with $100 \mathrm{mg}$ ginger $/ \mathrm{kg}$ body weight.

The experiment lasted for 60 days. One day after the final exposure, the animals were euthanized by overdose of chloroform. Blood was collected by cardiac puncture into EDTA sterilized sample bottles and used for the analysis of hemoglobin( $\mathrm{Hb}$ ), packed cell volume(PCV),red blood cells(RBC), white blood cells and erythrocyte indices-mean corpuscular volume (MCV), mean corpuscular hemoglobin ( $\mathrm{MCH})$, mean corpuscular hemoglobin concentration(MCHC). The results showed that gasoline alone decreased the levels of $\mathrm{Hb}, \mathrm{RBC}, \mathrm{WBC}, \mathrm{PCV}, \mathrm{MCV}$ and $\mathrm{MCHC}$, but it had no significant effect on the $\mathrm{MCH}$ of the rats. However, treatments with ginger extracts nearcompletely abrogated /mitigated any effects that have been induced by inhalation of gasoline alone. It appears that ginger extracts inhibited the chain reaction, caused by free radicals, and acted to remove the catabolic wastes from the lymphocytes and reticulocytes, thereby accelerating metabolism and lymph drainage. It also appears that ginger extracts promoted the sloughing-off of wasted tissues and corrected the imbalance of elevated inflammatory prostaglandins, leading to increased erythrocytes synthesis and improved immune system.
\end{abstract}

KEYWORDS: Ginger, gasoline, lead, nitrate and immunotoxicities.

\section{INTRODUCTION}

Humans are daily exposed to petroleum products, which are used for various reasons such as fuels for vehicles, cooking and lightning fuels in homes, chemical feedstocks for industries as well as therapeutic uses (Kuschener and Stark, 2003). Exposure to petroleum products has been reported to be genotoxic, mutagenic, immunotoxic, carcinogenic and nuerotoxic (Kato et al,1993; Anderson et al,1995). Constituents of gasoline include hydrocarbons like bezene, metals like lead and volatile nitrate, and have been shown to produce harmful effects on the bone marrow, spleen, and lymph nodes, resulting in chemical stress (Marieb,1995; d'Azevedo et al,1996;Smith et al,1996; Rabble and Wong,1996; Ross, 1996; Rothman et al,1996). Lead (lead tetra ethyl) causes insomnia, headache, irritability and confusion, leading to encephalopathy, neuropathy, abdominal colic, anemia and porphyria (Chatterjee and Shinde, 2000). Nitrate can be reduced to nitrite. Nitrite is toxic to erythrocytes and causes anemia, hemodilution, fluid retention and bone marrow depression (Smith et al, 1993; Kato et al, 1993; Ovuru and Ekweozor, 2004). Ginger (Zingiber Officinale) is used as a spice in cooking throughout the world. The characteristic odour and flavour of ginger is caused by a mixture of gingerone, shoagols, and gingerols, volatile oils that compose about $1-3 \%$ weight of fresh ginger. These are phenylpropanoid-derived compounds. The shoagols are formed from gingerols when ginger is dried or cooked. Gingerone is also produced from gingerols during this process, and it is less pungent and has a sweet aroma(McGee,2004). The main constituents of ginger are sesquiterpenoids with zinberene as the main component. Other components include $\beta$-sesquipheuandrene, bisabolene, and farnesene, which are also sesquiterpenoids. However, small amounts of monoterpenoid fraction such as $\beta$ phellandrene, cineol and citral are contained in ginger (O'Hara et al, 1998). The gingerols increase the motility of the gastrointestinal tract, and may be used as stomach settler; have analgesic, sedative and antibacterial properties (O'Hara, 1998). Ginger has a sialague action, stimulating the production of saliva, and may be used for treating dyspepsia and colic; promotes the release of bile from the gall bladder. It decreases joint pain from arthritis; possesses blood thinning and cholesterol lowering properties (O'Hara et al,1998). It has been found effective for treating nausea caused by morning sickness, seasickness and chemotherapy(ErnstandPittler,2000);inflammation, rheumatism,cold, heat cramps, and diabetes(ALAmin,2006; Afshari,2007).

The current study therefore focused on assessment of how ginger extracts could impact upon the immunotoxicities associated with exposure to gasoline in wistar rats exposed daily to gasoline and ginger.

G. O. Obochi, Department of Chemistry/Biochemistry, Cross River University of Technology, Calabar, Nigeria.

S. P. Malu, Department of Chemistry/Biochemistry, Cross River University of Technology, P.M.P 1123 Calabar Calabar, Nigeria.

A. E. Abara, Department of Chemistry/Biochemistry, Cross River University of Technology, Calabar, Nigeria.

O. R. Ogri, Department of Chemistry/Biochemistry, Cross River University of Technology, Calabar, Nigeria.

N. O. Alobi, Department of Chemistry/Biochemistry, Cross River University of Technology, Calabar, Nigeria. 


\section{MATERIAL AND METHODS}

\section{Experimental Animals}

Fifteen wistar albino rats weighing between $150 \mathrm{~g}-270 \mathrm{~g}$ obtained from the disease free stock of the animal house, Department of Biochemistry, College of Medical Sciences, University of Calabar, Nigeria, were used for the study. The animals were randomly assigned into three study groups of five (5) animals per group. Each rat in a study group was individually housed in a stainless cage with plastic bottom grid and a wire screen top. The animal room was adequately ventilated, and kept at room temperature and relative humidity of $29 \pm 2^{\circ} \mathrm{C}$ and $40-70 \%$,respectively, with 12 hours natural light-dark cycle. The animals were fed ad libitum with water and rat chow (Livesstock feeds Ltd, Calabar, Nigeria). Good hygiene was maintained by constant cleaning and removal of faeces and spilled feeds from cages daily. All animals' experiments were approved by the Animal Care and Use Committee of the Medical College, University of Calabar, Nigeria.

\section{Treatment Regimen}

The animals in groups 2 and 3 received daily treatment by inhalation of gasoline vapour for a period of 60 days, while the animals in group 3 were also treated with $100 \mathrm{mg}$ ginger $/ \mathrm{kg}$ body weight. The rats in groups 1 (the control) received a placebo(distilled water). The rats in groups 2 and 3 were daily exposed to $300 \mathrm{ml}$ gasoline in a $500 \mathrm{ml}$ glass beaker,placed in each cage containing rats. All treatments were conducted and monitored to ensure that the evaporated gasoline was refilled each day.

\section{Preparation of Ginger (zinger officinale)}

Fresh ginger (zinger officinale) were obtained from the Watt Market (Calabar, Nigeria) for use in the study. The gingers were air dried for 7 days, and ground into fine powder. A stock solution was prepared by dissolving $20 \mathrm{~g}$ of the finely ground ginger powder in $500 \mathrm{ml}$ distilled water, boiled for $30 \mathrm{~min}$, and allowed to cool to room temperature. The ginger extract was then filtered using cheese cloth. From this, and based on the animals weight that morning, the $100 \mathrm{mg} / \mathrm{kg}$ dosages were administered to the animals in group 3 as part of the $10.0 \mathrm{ml}$ volume used for gastric inhibition.

\section{Preparation of sample}

One day after the final exposure, the animals were euthanized by inhalation of overdose of chloroform. Blood was collected by cardiac puncture into EDTA sterilized sample bottles, and used for the analysis of hemoglobin $(\mathrm{Hb})$,packed cell volume (PCV)(hematocrit) ,red blood cells(RBCs), white blood cells (WBCs), and erythrocyte indices (mean corpuscular volume [MCV], mean corpuscular hemoglobin [MCH], mean corpuscular hemoglobin concentration $[\mathrm{MCHC}]$ ).

\section{Determination of total hemoglobin}

Total hemoglobin was determined by the specrophotometric method (Cyanmethamoglobin method) described by Taylor (1989). Whole blood of 2.0 $\mathrm{ml}$ each was pipetted into tubes. The blank received $2.0 \mathrm{ml}$ distilled water. Then, $5.0 \mathrm{ml}$ of potassium ferricyanide solution (1.0 $\mathrm{NaHCO}_{3}, 50 \mathrm{mg} \quad \mathrm{KCN}$, and
$200 \mathrm{mg} \mathrm{K}_{2}(\mathrm{CN})_{6}$ in $\left.1 \mathrm{~L}\right)$ was added to all tubes, covered with parafilm and gently mixed. The tubes were then incubated at $37^{\circ} \mathrm{C}$ for $10 \mathrm{~min}$, and the absorbances read at $540 \mathrm{~nm}$ in $6400 / 6405$ spectrophotometer (Jenway, Essex, England) against a reaction blank.

\section{Determination of packed cell volume (hematocrit)}

The packed cell volume (PVC) was determined by the micro-hematocrit method described by Taylor (1989). Capillary tubes were filled with whole blood by capillary action and the pack bottom end of the capillary tubes was filled with clay, and spun in a centrifuge at $4000 \times \mathrm{g}$ for $30 \mathrm{~min}$ to pack the red blood cells. This method was repeated for the second hematocrit tube. The two tubes were centrifuged at $6000 \times \mathrm{g}$ for $5 \mathrm{~min}$ against each other, and the percentage cell volume was read by sliding the tubes along a critocap chart until the meniscus of the plasma intersects the $100 \%$ line. The average value (triplicate) was recorded. The hemotocrit value was calculated as the ratio of height of cell over the total height of fluid in the tube.

\section{Determination of red blood cells}

Red cells were estimated by standard hemocytometric method described by Teitz (1982).

The sample collection tubes were completely filled with whole blood, inverted several times to adequately mix the blood samples and the anticoagulant (EDTA). The tubes were then placed in an improved Neubauer counting chamber under an Olympus binocular electric microscope.

\section{Determination of white blood cells}

White blood cells were estimated by standard hemocytometric method described by Teitz (1982). The sample collection tubes were completely filled with whole blood, inverted gently several times to mix the blood samples and the anticoagulant (EDTA). The tubes were then placed in an improved Neubauer counting chamber under an Olympus binocular electric microscope.

\section{Determination of erythrocytes indices}

Erythrocytes indices were estimated by the standard hematocytometric method described by Teitz (1982). The erythrocyte indices were calculated. MCV, the ratio of hematocrit (packed cell volume - PCV) to the red blood cell count (i.e. MCV=PCV/RBC), expresses the average size of the erythrocytes. $\mathrm{MCH}$, the ratio of hemoglobin to red blood cells count (i.e. $\mathrm{MCH}$, the ratio of hemoglobin to red blood cell count (i.e $\mathrm{MCH}=\mathrm{Hb} / \mathrm{RBC}$ ), gives the weight of hemoglobin weight to hematocrit (i.e $\mathrm{MCHC}=\mathrm{Hb} / \mathrm{PCV}$ ), defines the concentration of hemoglobin in $100 \mathrm{ml}$ of packed red cells.

\section{Statistical Analysis}

Data collected were expressed as mean \pm standard deviation (SD), and the student' $t$ ' test was used for analysis. Value of $\mathrm{P}<0.05$ were regarded as significant.

\section{RESULTS}

Table 1 presents the results of treatments on erythrocytes indices of the rats. The red cell indices or 
erythrocyte indices provide important information about size, hemoglobin concentration and hemoglobin weight of an average red cell. The results showed that there were no significant effects on the mean corpuscular hemoglobin $(\mathrm{MCH})$ relative to those of the controls. However, there were significant decrease $(P<0.05)$ in the value of hemoglobin, packed cells (WBCs) and some erythrocyte indices, particularly, mean corpuscular volume (MCV) and mean corpuscular hemoglobin concentration (MCHC) in the blood of the gasolinetreated animals relative to those seen in the controls.

Table 1: Effect of treatments on erythrocyte indices of the rats.

\begin{tabular}{|l|l|l|l|l|l|l|l|}
\hline Group(N) & $\mathrm{Hb}$ & $\mathrm{PCV}$ & $\mathrm{RBC}$ & $\mathrm{WBC}$ & $\mathrm{MCV}$ & $\mathrm{MCH}$ & $\mathrm{MCHC}$ \\
& $(\mathrm{g} / \mathrm{dl})$ & $(\%)$ & $\left(\times 10^{6} / \mathrm{mm}^{3}\right)$ & $\left(\times 10^{3} / \mathrm{mm}^{3}\right)$ & $(\mathrm{fured}$ cell $)$ & $((\mathrm{pg} / \mathrm{red}$ cell $)$ & $(\%)$ \\
\hline 1.Control & $16.27 \pm 0.24$ & $38.51 \pm 0.31$ & $6.89 \pm 0.41$ & $6.75 \pm 0.37$ & $98.94 \pm 0.47$ & $28.86 \pm 0.21$ & $37.22 \pm 0.34$ \\
\hline 2.Gasoline & $10.39 \pm 0.18^{*}$ & $23.25 \pm 0.22^{*}$ & $4.27 \pm 0.24^{*}$ & $4.12 \pm 0.28^{*}$ & $57.73 \pm 0.32^{*}$ & $28.79 \pm 0.20^{*}$ & $25.89 \pm 0.23^{*}$ \\
\hline $\begin{array}{l}\text { 3.Ginger + } \\
\text { Gasoline }\end{array}$ & $15.99 \pm 0.23 \#$ & $38.24 \pm 0.30 \#$ & $6.68 \pm 0.34 \#$ & $6.53 \pm 0.32 \#$ & $97.89 \pm 0.43 \#$ & $28.84 \pm 0.20 \#$ & $36.89 \pm 0.32 \#$ \\
\hline
\end{tabular}

$\mathrm{N}=$ Number of rats per group $=5$. Values are expressed as mean $\pm \mathrm{SD}$.

* Significantly different from control at $p<0.05$

\# significantly different from gasoline only at $\mathrm{P}<0.05$.

Co-exposure to the ginger with the gasoline appeared to completely blunt the effect of gasoline on these parameter-values of each index or parameter were almost universally equivalent to those seen in the controls.

\section{DICUSSION}

In this study, exposure to gasoline alone decreased the levels of hemoglobin $(\mathrm{Hb})$,red blood cells (RBCs), hematocrit (packed cell volume-PCV), white blood cells (WBCs), and erythrocytes indices, mean corpuscular volume (MCV), and mean corpuscular hemoglobin concentration (MCHC), but it had no significant effect on the mean corpuscular hemoglobin $(\mathrm{MCH})$ of the rats. However, treatments with ginger extracts nearcompletely abrogated/mitigated any effects that have been induced by inhalation of gasoline alone.

The effect of gasoline could be attributed to the oxidation-reduction of benzene, lead and nitrate components in gasoline in the red marrow. Oxidation of hemoglobin to met hemoglobin converted $\mathrm{Fe}^{2+}$ to $\mathrm{Fe}^{3+}$, making it incapable of binding oxygen, causing accumulation of oxygen, generating free radicals, which promoted a chain reaction, and caused destruction of erythrocytes, and DNA, leading to anemia, fluid retention(fluid overload), hemodilution, bone marrow depression ( leukopenia) and leukaemia (Marieb, 1995).

The toxicity of lead (lead tetra ethyl) could be due to blockage of spindle fiber mechanism in cell division, uncoupling oxidative phosphorylation; inhibition of enzymatic steps of heme-synthesis, particularly, $\delta$ amino laevulinic acid synthetase (ALA synthetase ) and aminolaevulinic acid dehydratase (ALAdehydratase);inhibition of uptake of iron( $\mathrm{Fe}$ ) by the reticulocytes from transferring ; and inhibition of ferrochelatase, causing an increased levels of free erythrocytes protoporphyrins (Chatterjee and Shinde,2000).

Generally, heavy metals have great affinity for sulphur and can attack sulphur bonds in enzymes, thus immobilizing the enzymes; bind to cell membrane, affecting transport processes through the cell walls; and precipitate phosphate biocompounds or catalyze their decomposition (Ndodigha et al, 1999; Chatterjee and Shinde, 2000).

The toxicity of nitrate could involve its reduction to nitrate, making the nitrite ion an electron acceptor, which accepts electron from oxygen molecule. This effect increases the rate of oxidation of hemoglobin to met hemoglobin (Ndodigha et al, 1999). Also, impairment of reduction of methemoglobin to hemoglobin causes accumulation of oxygen (Smith et al, 1993). Also, reduction of met hemoglobin to hemoglobin requires $\mathrm{NADPH}$, which is generated through pentose phosphate pathway, and nitrate inhibits the enzyme, glucose-6phosphate dehydrogenase in the erythrocytes, resulting in increased methemoglobin (Ovuru and Ekweozor, 2004). The toxicity of benzene could involve inhibition of the hematopoietic component in the bone marrow, causing depression of the bone marrow, spleen, and lymph nodes, leading to leukemia, and bone marrow hypoplasia(Marieb,1995; Rabble and Wong,1996;Smith et al ,1996; d'Azevedo et al,1996;Ross,1996;Rothman et al,1996). The resultant bone marrow depression is characterized by inadequate production of red blood cells and white cells (Rabble and Wong, 1996).

Depressed levels of the white blood cells could be attributed to induction of leukocytopaenia, pancytopaenia or bone marrow aplasia, which impaired migration of phagocytic cells, thereby lowering resistance to viruses, bacteria and foreign bodies, leading to reduced immune system (d'Azevedo et 
al,1995; Rabble and Wong,1996), and respiratory distress syndrome(Van maanen et al,1996).

The mechanism of free radical $\left(\mathrm{O}_{2}^{-}\right)$toxicity appears to involve powerful oxidant activity, which alters nucleic acids and polysaccharides, and oxidizes thiol groups (i.e conversion of S-H group to S-S group), in protein (Chatterjee and Shinde, 2000). Active free radicals are able to break covalent bonds by hemolytic fission, generating more free radicals, one of which typically combines with the attacking radical to form a new covalent bond and the second is available to attack a further bond and thus continues, forming a chain reaction(Chatterjee and Shinde,2000). Therefore, it appears that ginger acted to inhibit this chain reaction.

The low level of MCV and MCHC observed could indicate microcytic or hypochromic anemia, caused by iron deficiency, pyridoxine-response deficiency and thalaselmia (Leob and Hamilton, 2005). However, treatments with ginger extracts near completely abrogated/mitigated any effects that have been induced by inhalation of gasoline alone. Though, the mechanism of action of ginger may not be known, it appears that ginger inhibited the chain reaction caused by free radicals. The effects of ginger extracts on free radical toxicity could be attributed to the inhibition of the chain reaction caused by free radicals. The effects of ginger extracts on nitrate toxicity could be attributed to the activation of the enzyme, glucose-6-phosphate dehydrogenase in the erythrocytes, which resulted in an increased influx of glucose through the phosphogluconate pathway, leading to the production of $\mathrm{NADPH}$, which activated the reduction of methemoglobin to hemoglobin. The effects of ginger extracts on benzene toxicity could be attributed to the activation of the hematopoietic component in the red marrow, which activated the bone marrow, spleen and lymph nodes, which in turn, activated the migration of phatocytic cells, leading to increased production of red blood cells and white blood cells which resulted in improved immune system. The effects of ginger extracts on lead toxicity could be attributed to the opening of the spindle mechanism in cell division, and activation of the enzymatic steps in hemesynthesis; activation of uptake of iron ( $\mathrm{Fe})$ by the reticulocytes, and activation of the enzyme, ferro-chelatase, leading to increased erythrocytes synthesis and improved immune system.

In conclusion, the results from this study have shown that gasoline alone decreased the level of $\mathrm{Hb}, \mathrm{RBC}$, WBC, PCV and erythrocytes indices, MCV and $\mathrm{MCHC}$, but it had no significant effect on the $\mathrm{MCH}$ of the rats. However, treatments with ginger extracts near completely abrogated/mitigated any effects that have been induced by inhalation of gasoline alone. It appears that ginger extracts inhibited the chain reaction caused by free radicals; and acted to remove the catabolic wastes from the lymphocytes and reticulocytes, thereby accelerating metabolism and lymph drainage. Ginger also acted to promote the sloughing-off of wasted tissues, and corrected the inbalance of elevated inflammatory prostaglandins, leading to increased erythrocytes synthesis and improved immune system. The results of this study may suggest that ginger extracts may be useful in the treatment of toxicities or diseases associated with gasoline inhalation. It also suggest that ginger extracts could be used as a system cleanser, which may remove the catabolic wastes from the lymphocytes and reticulocytes, thereby accelerating metabolism and lymph drainage, which in turn, could lead to an improvement in immune system. ginger extracts also could be used in the treatment of gasoline associated respiratory disorders such as asthma.

\section{REFERENCES}

Anderson, D., Yu, T.W. and Schmeizer, P. (1995).An Investigation of the DNA-damaging ability of benzene and its metabolites in human lymphocytes using the Comet Assay.Environ.Molec.Mutat.26:305-314.

Afshari, A. T., 2007. Effect of ginger on diabetic neuropathy, plasma antioxidant capacity and lipid peroxidation in rats. Food Chemistry, 101(1):148-153.

Al-Amin, Z. M., 2006. Antidiabetic and hypolipidaemic properties of zingiber (zingiber officinale) in streptozotocin-induced diabetic rats .British Journal of Nutrition 96: 660 - 666.

Austin, H., Delzell, E. and Cole, P., 1988. Benzene and Leukemia.A Review of the literature and risk assessment.American Journal of Epidemiology.127: 419 - 425.

Chatterjee, M. N. and Shinde, R., 2000. Lead,benzene and nitrate In:Textbook of Medical Biochemistry. $5^{\text {th }}$ Edition.J.P.Vij and R.K Yadav (eds).Jaypee Brothers Medical Publishers(P) Ltd.New Delhi.pp. 700 - 702.

d'Azevdo, P. A., Tannhauser, A. L, and Tannhauser, S. L ., 1996. Haematological alterations in rats from xylene and benzene.Vet.Human Toxicol. 38(5): 340 344.

Dede, E. B and Kagbo,H. D., 2002. A study on the acute toxicological effect of commercial diesel fuel in Nigeria in rats(ratus ratus) using haematological parameters.Journal of Appl.Sci.Environ.Mgt. 6: $84-86$.

Ernst, E. and Pittler, M. H., 2000. Efficacy of ginger for nausea and vomiting: a systematic review of randomized clinical trials. British Journal of ANETHESIA, 84(3):367-371.

Kato, M., Rocha, M. L., Carvallo, A. B., Chaves, M. E., Rana, M. C, and Olverra, F. C., 1993. Occupational exposure to nuetratoxicants-preliminary Survey in five industries of Caricari Petrochemical Complex.Brazil Environ.Res. 61: 133-139.

Kuschener, W.G., Stark, P., 2003. Occupational toxicants exposures have an important role in many cases of lung diseases seen in workers.Occupational lung Diseases. Part 1. 
Identifying work-related asthma and other disorders. Postgrad. Med. 113(4): 70 - 78.

Leob, S. and Hamilton, H. K., 2005. Erythrocytes indices, In:Clinical Laboratory Test-Values and Implications. S. Leob and H. K. Hamilton (eds). Springhouse Corporation,Pennysylavania.pp. 247-248.

Marieb, E. N., 1995. Human Anatomy and Physiolog. $3^{\text {rd }}$ Edition.Benjamin and Commings Publishing Co.Ltd.California. pp. 585-611.

McGee, H., 2004. On food and cooking:The science and lore of the kitchen.2 ${ }^{\text {nd }}$ Edition.Harold McGee(ed).New York.pp.425-426.

Ndodigha, E. M., Olayinka, F. O., Oruwaric, B. M., Ekweozor, Ike, Wekhe, S. N., 1999. Toxic effect of crude oil on organs and bloods cells of West African dwarf Goats. Nig. Vet. Journal.20: 82 - 91.

O'Hara,M., Keifer. K., Kemper, 1998. A review of 12 commonly used medicinal herbs. Archives of Family Medicine (7): 523 - 536.

Ovuru, S.S. and Ekweozor, I. K. E., 2004. Haematological changes associated with crude oil ingestion in experimental rabbits.

Rabble, G. K. and Wang, O., 1996. Leukemia mortality by cell type in petroleum workers with potential exposure to benzene. Environ. Health Perspect.104: 1381 - 1392.

Ross, D., 1996. Metabolic basis of benzene toxicity: A review. Euro. J. Hematology. 60:111-118.

Rothman, N., Li, G.L., Dosemeci, M. Bechtold, W. E., Marti, G. E. and Wang, Y. Z., 1996. Haematoxicity among chines workers-heavily exposed to benzene. America J.Ind.Med.29 (3): 236-246.

Smith, J. H., Mallet, A. K. and Brautom, P. G., 1996. Ninety days feeding study in Fischer-344 rats of highly refined petroleum derived from grade white oils and waves. Toxicology Pathol. 24 : 214-230.

Smith, T. J., Hammon, S. K. and Wong. O., 1993. Health effect of gasoline exposure: Exposure assessment for US. Distribution workers. Environ. Health Perspectives 101:13021.

Taylor, H. E., 1989. Blod Analysis, In: Clinical Chemistry.H.E. Taylor (Ed), John Wiley and Sons, New York. Pp 729-825.

Teitz, N.W., 1982. BLOOD Analysis, In: Fundamentals of Clinical Chemistry.18 ${ }^{\text {th }}$ Edition. Norbert W.Teitz (ed).W.B.Saunders Company, London, pp885-907. 